\title{
Notice
}

\section{Nominations for the Editorship of Animal Learning \& Behavior}

Nominations are solicited for the editorship of Animal Learning \& Behavior. The term of the present editor, Vincent M. LoLordo, expires at the end of 1994. The new editor will begin an official 4-year term January 1, 1995. It is expected that the Publications Committee of the Psychonomic Society will make the appointment by November 1993 .

Nominations must be submitted by July 1, 1993.

Nominations (including self-nominations) should be sent to:

Michael Domjan

Department of Psychology

University of Texas

Austin, TX 78712 